\title{
5-Hydroxytryptamine-induced proliferation of pulmonary artery smooth muscle cells are extracellular signal-regulated kinase pathway depen- dent $^{1}$
}

\author{
Dan SONG, Huai-liang WANG ${ }^{2}$, Shuang WANG, Xin-hua ZHANG \\ Department of Clinical Pharmacology, China Medical University, Shenyang 110001, China
}

\section{Key words}

antisense oligodeoxyribonucleotides; serotonin; membrane transport proteins; pulmonary hypertension; vascular smooth muscle; fluxetine; mitogen-activated protein kinases

\footnotetext{
${ }^{1}$ Project supported in part by National Natural Science Foundation of China (№ 0271510) and the Science and Technology Committee of China (№ 9690105274).

${ }^{2}$ Correspondence to Prof Huai-liang WANG. Phn 86-24-2325-6666, ext 5547.

Fax 86-24-2324-6666, ext 5547.

E-mail hlwang@mail.cmu.edu.cn

Received 2004-07-15

Accepted 2004-11-10

doi: $10.1111 / \mathrm{j} .1745-7254.2005 .00071 . \mathrm{x}$
}

\begin{abstract}
Aim: To investigate the effect of 5-hydroxytryptamine transporter (5-HTT) inhibitor fluoxetine and antisense oligodeoxynucleotide (ODN) to extracelluar signalregulated kinases (ERKs) on pulmonary arterial smooth muscle cells (PASMCs) proliferation induced by 5-HT. Methods: Liposomal transfection was used to introduce ODNs to ERK1/2 into cultured rat PASMCs and the transfection efficiency was measured by observing the uptake of the fluorecein isothiocynate (FITC)-labeled antisense ODN in PASMCs. The effects of 5-HTT selective inhibitor fluoxetine and ODNs on the proliferation of PASMCs were evaluated by cell number counting and cell cycle analysis, and measured by microculture tetrazolium (MTT) assay and flow cytometry (FCM), respectively. Results: Liposomes mediated the transfection of ODNs into PASMCs with high efficiency. MTT assay showed fluoxetine $(10 \mu \mathrm{mol} / \mathrm{L}, 1 \mu \mathrm{mol} / \mathrm{L}$, and $100 \mathrm{nmol} / \mathrm{L})$ concentration dependently inhibited the proliferation of PASMCs induced by 5 -HT $(1 \mu \mathrm{mol} / \mathrm{L})$ in vitro. The proliferation rate of PASMCs by 5 -HT was significantly inhibited by pretreatment with ERK $1 / 2$ antisense ODN $(0.2 \mu \mathrm{mol} / \mathrm{L})$ from $251 \% \pm 18 \%$ to $86 \% \pm 5 \%$ $(P<0.01)$. Flow cytometric analysis of cell cycle distribution showed that the increase of 5-HT induced S phase fraction (SPF) and proliferation index (PI) were significantly inhibited by fluoxetine $(1 \mu \mathrm{mol} / \mathrm{L})$ or antisense ODN with SPF from $36 \% \pm 4 \%$ to $26 \% \pm 3 \%$ and $24 \% \pm 4 \%$, and PI from $34 \% \pm 2 \%$ to $29 \% \pm 2 \%$ and $24 \% \pm 2 \%$, respectively. Conclusion: 5-HTT mediates the mitogenic effect of 5-HT on PASMCs and the proliferation of PASMCs induced by 5-HT is dependent on ERKs signal pathway.
\end{abstract}

\section{Introduction}

Exposure to acute or chronic hypoxia leads to the development of pulmonary arterial hypertension (PAH). The cardinal features of PAH are persistent vasoconstriction and structural remodeling of the pulmonary vessels ${ }^{[1]}$. Hyperplasia of pulmonary artery smooth muscle cells (PASMCs) is the main component of pulmonary vascular remodeling which is associated with progressive elevation in pulmonary arterial pressure ${ }^{[2]}$. However, the exact mechanism of the proliferation of PASMCs was unclear.

Several studies have shown that 5-hydroxytryptamine (5-HT), endothelin-1 (ET), platelet derived growth factors
(PDGF), angiotensin II (Ang II), and epidermal growth factor (EGF) participate in the regulation of proliferation in PASMCs ${ }^{[3]}$. Among these mediators, 5-HT plays an important role in the pathogenesis of PAH. 5-HT exerts potent mitogenic and comitogenic effects on PASMCs, and these effects are associated with cellular internalization of 5-HT mediated by the 5hydroxytryptamine transporter $(5-\mathrm{HTT})^{[4,5]}$. Yet, it is not clear if inhibition of 5-HTT may abolish the proliferation of PASMCs to 5-HT.

Furthermore, mitogen activated protein kinases (MAPKs) are a superfamily of serine/threonine protein kinases distributed extensively in cytoplasm. Many stimuli resulting in cell 
growth, differentiation, and vascular contraction may activate MAP kinase-dependent signaling pathways.

Among this family, extracelluar signal-regulated kinases (ERKs) are activated in response to growth and differentiation factors ${ }^{[6-8]}$. Previous studies have shown that 5-HT induced ERK1/2 activation in rat aortic smooth muscle cells and rabbit isolated renal artery smooth muscle cells ${ }^{[9,10]}$. However, whether the intracelluar signal pathway of 5-HT in PASMCs is dependent on the ERKs activation is largely unconcerned. Therefore, the present study was designed to observe the effect of fluoxetine, a selective inhibitor of 5-HTT, on the proliferation of PASMCs in response to 5-HT, and then to study the effect of downregulation of ERK1/2, using antisense oligodeoxynucleotides (ODNs), on the proliferation of 5-HT-stimulated PASMCs in vitro.

\section{Materials and methods}

Drugs and reagents Dulbecco's modified Eagle's medium (DMEM), fetal bovine serum (FBS), and trypsin were purchased from Gibco Co (Grand Island, New York, USA). 5-HT and propidium iodide (PI) were purchased from Sigma Co (St Louis, USA). Lipofectin reagent was from Life Technologies Inc, Ltd (Rockville, USA). Fluoxetine hydrochloride was from Eli Lilly Co (Indianapolis, USA). ODNs were synthesized by Sangon (Shanghai, China).

Pulmonary artery smooth muscle cell culture Lungs were removed from male Wistar rats weighing 250-300 g (supplied by the Animal Center of China Medical University, Grade II, Certificate No LN 03-0009). Under aseptic conditions, proximal pulmonary arteries were isolated. After removing the tissue around the arteries, the pulmonary arteries were cut into small pieces about $1 \mathrm{~mm}^{2}$ and then seeded into 30-mm Petri dishes and cultured in DMEM (containing $20 \% \mathrm{FBS}, 100 \mathrm{kU} / \mathrm{L}$ of penicillin and $100 \mathrm{mg} / \mathrm{L}$ of streptomycin, $\mathrm{pH}$ 7.2). Then these explants were incubated at the atmosphere of $37{ }^{\circ} \mathrm{C}$ and $95 \% \mathrm{O}_{2} / 5 \% \mathrm{CO}_{2}^{[11]}$. When the cells had grown out from the explants and reached the confluence of more than $70 \%$, cells were passaged to T25 flasks. Cells used in experiments were from passages 3 to 9 .

Oligodeoxynucleotides On account of GCG package locating in the translation initiation region of rat ERK1/2 mRNA, the sequences of antisense ODN were designed as follows: 5'-GCC GCC GCC GCC GCC AT. This ODN has been used successfully to downregulte ERK $1 / 2$ in VSMCs, rat cardiac myocytes and rat cardiac fibroblasts ${ }^{[12]}$. Sense ODN (5'-AT GGCGGCGGC GGC GGC), random ODN (5'-CGCGCGCTC GCG CAC CC) were used as controls. All bases were protected by phosphorothioation. One batch of antisense ODN was labeled with fluorecein isothiocyanate (FITC) used in fluorescence microscopy experiments.

Microculture tetrazolium (MTT) assay Cells were seeded into 96-well plates at a density of $1 \times 10^{4}$ cells/well. The cells were then incubated in medium containing vehicle $(5 \%$ FCS DMEM) and 5-HT ( $1 \mu \mathrm{mol} / \mathrm{L})$ for $24 \mathrm{~h}$ with or without fluoxetine $(10 \mu \mathrm{mol} / \mathrm{L}, 1 \mu \mathrm{mol} / \mathrm{L}$, and $100 \mathrm{nmol} / \mathrm{L})$ added 30 $\mathrm{min}$ before 5 -HT. The effect of different ODNs $(0.2 \mu \mathrm{mol} / \mathrm{L})$ on the proliferation induced by 5-HT was also observed after transfection. The group with the cells incubated in serum-free medium was used as the control. At the end of this period, MTT ( $5 \mathrm{~g} / \mathrm{L})$ was added to each well, and incubation proceeded at $37^{\circ} \mathrm{C}$ for $4 \mathrm{~h}$. Thereafter, the medium was removed and the cells were solubilized in $150 \mu \mathrm{L} \mathrm{Me}_{2} \mathrm{SO}$. Optical density $(O D)$ of each well was determined by enzyme-linked ELISA at $490 \mathrm{~nm}$ of wavelength. Then the proliferation rates (PR) of each group were calculated.

$$
\mathrm{PR}=\left(O D_{\text {experiment }}-O D_{\text {control }}\right) / O D_{\text {control }}
$$

Flow cytometry (FCM) PASMCs grown in T25 plates were treated with fluoxetine or antisense ODN $(0.2 \mu \mathrm{mol} / \mathrm{L})$ before 5-HT was added. The cells were harvested by trypsinization, washed twice with $\mathrm{PBS}$, and the pellets were resuspended in $0.5 \mathrm{~mL}$ of PBS containing $100 \mathrm{mg} / \mathrm{L}$ RNase for incubation at $37^{\circ} \mathrm{C}$ for $30 \mathrm{~min}$. Then, $0.5 \mathrm{~mL}$ of PI solution $(100 \mathrm{mg} / \mathrm{L}$ in PBS$)$ was added, and the mixture was incubated in the dark at $4{ }^{\circ} \mathrm{C}$ for $30 \mathrm{~min}$. The cells were analyzed with a FACScan flow cytometer. Then S-phase cell fractions (SPF) and proliferation index (PI) of each group were calculated. $\mathrm{SPF}=\mathrm{S} /\left(\mathrm{G}_{0} \mathrm{G}_{1}+\mathrm{S}+\mathrm{G}_{2} \mathrm{M}\right) ; \mathrm{PI}=\left(\mathrm{G}_{2} \mathrm{M}+\mathrm{S}\right) /\left(\mathrm{G}_{0} \mathrm{G}_{1}+\mathrm{S}+\mathrm{G}_{2} \mathrm{M}\right)$.

Liposomal transfection Prior to transfection, PASMCs were cultured in serum-free medium for $24 \mathrm{~h}$. ODNs were mixed with antibiotic- and serum-free medium to a concentration of $0.8 \mu \mathrm{mol} / \mathrm{L}$, then mixed with equal volume of medium containing $80 \mathrm{mg} / \mathrm{L}$ of lipofectin and incubated at room temperature for $15 \mathrm{~min}$. ODN/lipofectin mix $20 \mu \mathrm{L}$ was added to each well of a 96 -well plate, $200 \mu \mathrm{L}$ to each well of a 12 -well plate, and $1000 \mu \mathrm{L}$ to the T25 plates, with equal volume of antibiotic- and serum-free medium. The cells were incubated for a further $6 \mathrm{~h}$ with gentle agitation every $2 \mathrm{~h}$. The medium was then replaced with the same volume of liposome-free medium containing the same concentration of ODN and 5\% FBS. Cells were incubated for another $24 \mathrm{~h}$ before MTT assay and FCM.

Fluorescence microscopy PASMCs were seeded into 12-well plate and transfected using FITC-labeled antisense ODN. After $24 \mathrm{~h}$ and $48 \mathrm{~h}$ of incubation, the cells were viewed by fluorescence microscopy.

Statistical analysis All the data are presented as mean $\pm \mathrm{SD}$, and assessed by ANOVA and $t$-test. $P<0.05$ was 
considered significant.

\section{Results}

Uptake of ODNs by PASMCs Twenty four hours after liposomal transfection, FITC-labeled antisense ODN were observed in both cytoplasm and the nuclei of PASMCs (Figure 1). More than $90 \%$ of the cells exhibited fluorescence.

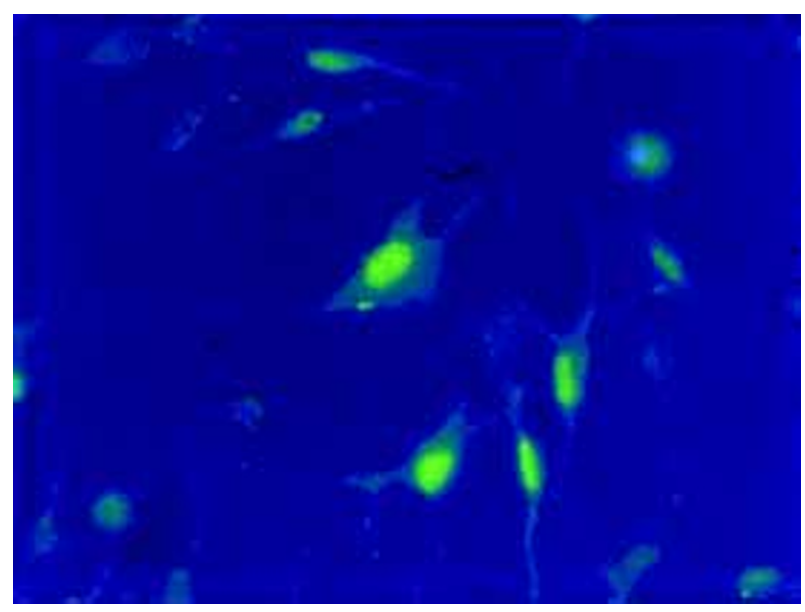

Figure 1. Fluorescence photomicrograph of PASMCs taken $24 \mathrm{~h}$ after transfection with the FITC-labeled antisense ODN $(\times 400)$. Fluorescence were observed in both cytoplasm and the nuclei of PASMCs.

Effect of fluoxetine and ODNs on the proliferation of PASMCs induced by 5-HT MTT assay showed that 5-HT (1 $\mu \mathrm{mol} / \mathrm{L})$ induced increased proliferation of PASMCs and the $\mathrm{PR}$ in response to 5 -HT increased from $172 \% \pm 5 \%$ to $217 \% \pm 4 \%$ compared with the vehicle. Pretreatment of the cells with fluoxetine $(10 \mu \mathrm{mol} / \mathrm{L}, 1 \mu \mathrm{mol} / \mathrm{L}$, and $100 \mathrm{nmol} / \mathrm{L})$ could produce a concentration-dependent reduction in PR (Figure 2). According to these results, $1 \mu \mathrm{mol} / \mathrm{L}$ was chosen as the concentration of fluoxetine used in following experiments.

Pretreatment of PASMCs with ERK1/2 antisense ODN resulted in a significant inhibition of 5-HT-induced PASMCs proliferation (Figure 3 ) and this inhibitory effect is rather more potent than fluoxetine. In contrast, sense ODN and random ODN did not have such effect.

Effect of fluoxetine and antisense ODN on cell cycle Flow cytometric analysis of cell cycle distribution showed that the cells treated with 5-HT had larger values of S-phase cell fraction (SPF) and PI than the vehicle. But pretreatment with fluoxetine or antisense ODN decreased these values (Figures $4,5)$. These results indicated that 5-HT promoted the PASMCs from the $\mathrm{G}_{0} / \mathrm{G}_{1}$ phase of the cell cycle into $S$ phase

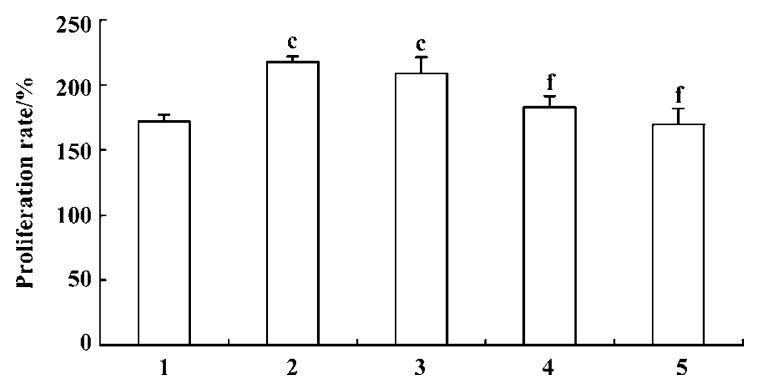

Figure 2. Effect of different concentrations of fluoxetine on the proliferation of PASMCs induced by 5-HT. Experimental groups: 1) vehicle (5\% FBS DMEM); 2) 5-HT (1 $\mu \mathrm{mol} / \mathrm{L})$; 3) 5-HT (1 $\mu \mathrm{mol} / \mathrm{L})$ +fluoxetine $(100 \mathrm{nmol} / \mathrm{L})$; 4) 5-HT $(1 \mu \mathrm{mol} / \mathrm{L})+$ fluoxetine $(1 \mu \mathrm{mol} / \mathrm{L})$; 5) 5 -HT $(1 \mu \mathrm{mol} / \mathrm{L})+$ fluoxetine $(10 \mu \mathrm{mol} / \mathrm{L}) . \quad n=3 .{ }^{\mathrm{c}} P<0.01 \mathrm{vs}$ control. ${ }^{\mathrm{f}} P<0.01$ vs 5 -HT $(1 \mu \mathrm{mol} / \mathrm{L})$.

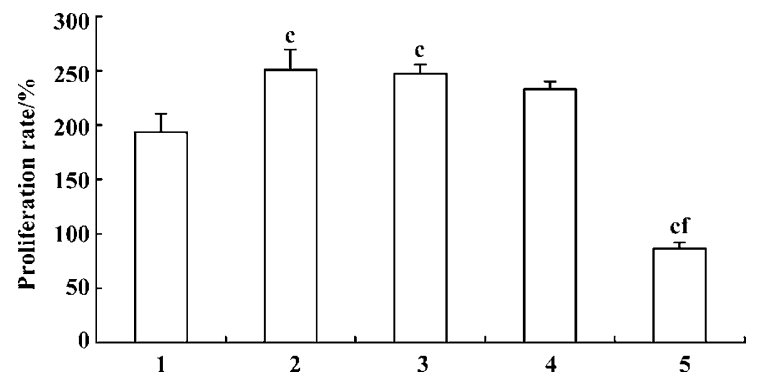

Figure 3. Effect of different ODNs on the proliferation of PASMCs induced by 5-HT. Experiment groups: 1) vehicle (5\% FBS DMEM); 2) 5 -HT $(1 \mu \mathrm{mol} / \mathrm{L})$; 3$) 5$-HT $(1 \mu \mathrm{mol} / \mathrm{L})+$ random ODN $(0.2 \mu \mathrm{mol} / \mathrm{L})$; 4) 5 -HT $(1 \mu \mathrm{mol} / \mathrm{L})+$ sense ODN $(0.2 \mu \mathrm{mol} / \mathrm{L})$; 5$) 5$-HT $(1 \mu \mathrm{mol} / \mathrm{L})$ + antisense ODN $(0.2 \mu \mathrm{mol} / \mathrm{L}) . \quad n=3 .{ }^{\mathrm{c}} P<0.01 v s$ control. ${ }^{\mathrm{f}} P<0.01 v s$ 5-HT (1 $\mu \mathrm{mol} / \mathrm{L})$.

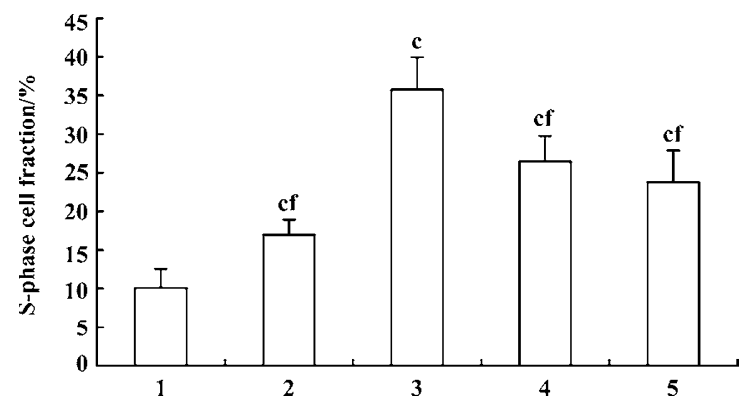

Figure 4. Effect of fluoxetine and antisense ODN on S-phase cell fraction of PASMCs. Experiment groups: 1) control; 2) vehicle (5\% FBS DMEM); 3) 5-HT ( $1 \mu \mathrm{mol} / \mathrm{L})$; 4) 5-HT ( $1 \mu \mathrm{mol} / \mathrm{L})+$ fluoxetine $(1 \mu \mathrm{mol} / \mathrm{L}) ; 5) 5$-HT $(1 \mu \mathrm{mol} / \mathrm{L})+$ antisense ODN $(0.2 \mu \mathrm{mol} / \mathrm{L}) . \quad n=3$. ${ }^{\mathrm{c}} P<0.01$ vs control. ${ }^{\mathrm{f}} P<0.01$ vs $5-\mathrm{HT}(1 \mu \mathrm{mol} / \mathrm{L})$.

and this effect was inhibited by fluoxetine and antisense ODN. 


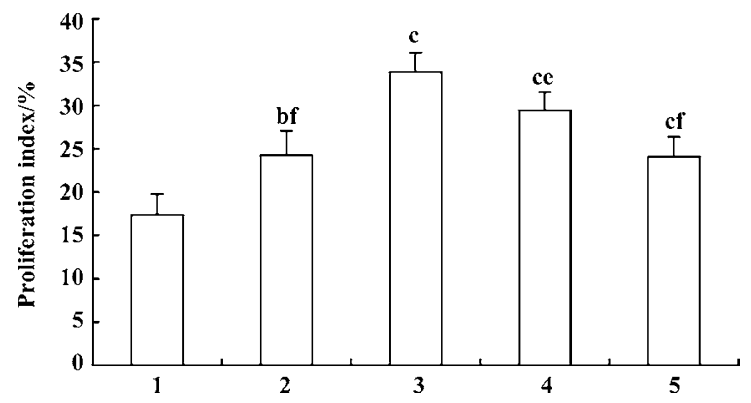

Figure 5. Effect of fluoxetine and antisense ODN on proliferation index of PASMCs. Experiment groups: 1) control; 2) vehicle (5\% FBS DMEM); 3) 5-HT $(1 \mu \mathrm{mol} / \mathrm{L})$; 4$) 5$-HT $(1 \mu \mathrm{mol} / \mathrm{L})+$ fluoxetine $(1 \mu \mathrm{mol} / \mathrm{L}) ; 5) 5-\mathrm{HT}(1 \mu \mathrm{mol} / \mathrm{L})+$ antisense ODN $(0.2 \mu \mathrm{mol} / \mathrm{L}) . n=3$. ${ }^{\mathrm{b}} P<0.05,{ }^{\mathrm{c}} P<0.01$ vs control. ${ }^{\mathrm{e}} P<0.05,{ }^{\mathrm{f}} P<0.01$ vs 5 -HT $(1 \mu \mathrm{mol} / \mathrm{L})$.

\section{Discussion}

Results from the present study demonstrated that 5-HTT played a key role in the mitogenic effect of 5-HT on PASMCs. Fluoxetine, a highly selective inhibitor of 5-HTT inhibited the proliferation of PASMCs induced by 5-HT in vitro. Meanwhile, antisense ODN to ERK1/2 inhibited 5-HT-induced proliferation of PASMCs. These findings suggest that 5-HT-induced proliferation of PASMCs is 5-HTT and ERK pathway dependent.

In response to hypoxia, 5-HT is released from pulmonary neuroendocrine cells and neuroepithelial bodies distributed throughout the airways. An increase in 5-HT may contribute to secondary pulmonary artery hypertension ${ }^{[13]}$. The proliferation of PASMCs induced by 5-HT is an important component of pulmonary arterial remodeling. RT-PCR analyses of PASMCs indicated the presence of 5- $\mathrm{HT}_{1 \mathrm{~B} / \mathrm{D}}, 5-\mathrm{HT}_{2}$ receptors and 5-HTT mRNA ${ }^{[14,15]}$. The present results show that the proliferation of PASMCs induced by 5 -HT is inhibited by fluoxetine in a manner that is concentrationdependent. In contrast, the $5-\mathrm{HT}_{1 \mathrm{~B} / \mathrm{D}}$ receptor antagonist GR127935, the 5- $\mathrm{HT}_{2 \mathrm{~A}}$ receptor antagonist ketanserin, or the $5-\mathrm{HT}_{2 \mathrm{~B} / 2 \mathrm{C}}$ receptor antagonist SB206553 had no this effect ${ }^{[16]}$. It has been recently reported that exposure of PASMCs to hypoxia increased 5-HTT expression and activity, and this effect was associated with potentiation of the mitogenic action of 5-HT ${ }^{[5,17]}$. Some scholars found that mice deficient in 5-HTT or treated with selective inhibitors of 5-HTT developed less PAH than controls when exposed to hypoxia ${ }^{[18,19]}$. These evidences suggest that 5-HTT in PASMCs may be a key determinant of pulmonary arterial remodeling and the development of PAH. Therefore, our result means that 5-HTT is one of the important mechanisms of PAH and this may provide a novel therapeutic target for $\mathrm{PAH}$.
The uptake of FITC-labeled antisense ODN by PASMCs with liposomes proved the high efficiency of transfection. In the present study, the antisense ODN to ERK1/2 delivered by lipofectin resulted in an effective suppression of the proliferative response to 5-HT in PASMCs. Meanwhile, the effect of antisense ODN stronger than fluoxetine suggests that antisense ODN to ERK1/2 could inhibit the proliferation of PASMCs not only induced by 5-HT, but also by the serum $^{[20]}$. The present study proves that $5-\mathrm{HT}$ induced the proliferation of PASMCs and is dependent on the activation of ERK1/2. Therefore, it is reasonable to consider that 5-HT induced activation of ERKs through 5-HTT in PASMCs. Previous studies showed that 5-HT induced the Tyr phosphorylation of GTPase-activating protein (GAP) and the effect was mediated by 5-HTT, which was the upstream of the ERK pathway, not by 5-HT receptors ${ }^{[21]}$. The mechanism of 5-HT signaling for PASMCs through 5-HTT has also been shown to involve the production of reactive oxygen species (ROS) such as superoxide and $\mathrm{H}_{2} \mathrm{O}_{2}$ via the activation of $\mathrm{NAD}(\mathrm{P}) \mathrm{H}$ oxidase, and the activation of the ERK pathway occurs secondary to ROS formation ${ }^{[22,23]}$. Therefore, the activation of ERKs induced by $5-\mathrm{HT}$ is mediated by 5 -HTT.

The present study showed that fluoxetine concentrationdependently inhibited 5-HT-induced proliferation of PASMCs in vitro, and demonstrated that antisense ODN to ERK1/2 significantly inhibited mitogenesis of PASMCs. Therefore, we concluded that 5-HT-induced mitogenesis of PASMCs was mediated by 5-HTT, in which the signal transduction for 5-HT was dependent on ERKs signal pathway.

\section{References}

1 Fishman AP. Clinical classification of pulmonary hypertension. Clin Chest Med 2001; 22: 385-91.

2 Jeffery TK, Morrell NW. Molecular and cellular basis of pulmonary vascular remodeling in pulmonary hypertension. Prog Cardiovasc Dis 2002; 45: 173-202.

3 Eddahibi S, Morrell N, d'Ortho MP, Maeije R, Adnot S. Pathobiology of pulmonary arterial hypertension. Eur Respir J 2002; 20: 1559-72.

4 Lee SL, Wang WW, Lanzillo JJ, Fanburg BL. Serotonin produces both hyperplasia and hypertrophy of bovine pulmonary artery smooth cells in culture. Am J Physiol 1994; 266: L46-52.

5 Eddahibi S, Fabre V, Boni C, Martres MP, Raffestin B, Hamon M, et al. Induction of serotonin transporter by hypoxia in pulmonary vascular smooth muscle cells. Relationship with the mitogenic action of serotonin. Circ Res 1999; 84: 329-36.

6 Robinson MJ, Cobb MH. Mitogen-activated protein kinase pathways. Curr Opin Cell Biol 1997; 9: 180-6.

7 Force T, Bonventre JV. Growth factors and mitogen-activated protein kinases. Hypertension 1998; 31: 152-61.

8 Florian JA, Watts SW. Integration of mitogen-activated protein 
kinase kinase activation in vascular 5-hydroxytryptamine $2 \mathrm{~A}$ receptor signal transduction. J Pharmacol Exp Ther 1998; 284: 346-55.

9 Watts SW, Yang P, Banes AK, Baez M. Activation of Erk mitogen-activated protein kinase proteins by vascular serotonin receptors. J Cardiovasc Pharmacol 2001; 38: 539-51.

10 Hinton JM, Hill P, Jeremy J, Garland C. Signalling pathways activated by $5-\mathrm{HT}_{1 \mathrm{~B}} / 5-\mathrm{HT}_{1 \mathrm{D}}$ receptors in native smooth muscle and primary cultures of rabbit renal artery smooth muscle cells. J Vasc Res 2000; 37: 457-68.

11 Rothman A, Kulik TJ, Taubman MB, Berk BC, Smith CW, NadalGinard B. Development and characterization of a cloned rat pulmonary arterial smooth muscle cell line that maintains differentiated properties through multiple subcultures. Circulation 1992; 86: 1977-86.

12 Huang SL, Ding B, Yu QS, Guo ZG. Effect of antisense mitogenactivated protein kinase oligonucleotides on rat vascular smooth muscle cell proliferation induced by EGR in vitro. Acta Pharmacol Sin 1998; 19: 489-93.

13 MacLean MR, Herve P, Eddahibi S, Adnot S. 5-Hydroxytryptamine and the pulmonary circulation: receptors, transporters and relevance to pulmonary arterial hypertension. $\mathrm{Br} \mathrm{J}$ Parmacol 2000; 131: 161-8.

14 Ullmer C, Schmuck K, Kalkman HO, Lubbert H. Expression of serotonin receptor mRNAs in blood vessels. FEBS Lett 1995; 370: 215-21.

15 Ramamoorthy S, Bauman AL, Moore KR, Han H, Yang-Feng T, Chang AS, et al. Antidepressant- and cocaine-sensitive human serotonin transporter: molecular cloning expression and chromosomal location. Proc Natl Acad Sci USA 1993; 90: 2542-6.
16 Marcos E, Adnot S, Pham MH, Nosjean A, Raffestin B, Hamon $\mathrm{M}$, et al. Serotonin transporter inhibitors protect against hypoxic pulmonary hypertension. Am J Respir Crit Care Med 2003; 168: 487-93.

17 Eddahibi S, Humbert M, Fadel E, Raffestin B, Darmon M, Capron $\mathrm{F}$, et al. Serotonin transporter overexpression is responsible for pulmonary artery smooth muscle hyperplasia in primary pulmonary hypertension. J Clin Invest 2001; 108: 1141-50.

18 Marcos E, Adnot S, Pham MH, Nosjean A, Raffestin B, Hamon $\mathrm{M}$, et al. Serotonin transporter inhibitors protect against hypoxic pulmonary hypertension. Am J Respir Crit Care Med 2003; 168: 487-93.

19 Eddahibi S, Hanoun N, Lanfumey L, Lesch KP, Raffestin B, Hamon $\mathrm{M}$, et al. Attenuated hypoxic pulmonary hypertension in mice lacking the 5-hydroxytryptamine transporter gene. J Clin Invest 2000; 105: 1555-62.

20 Fisher M, Liu B, Glennon PE, Southgate KM, Sale EM, Sale GJ, et al. Downregulation of the ERK 1 and 2 mitogen activated protein kinases using antisense oligonucleotides inhibits proliferation of porcine vascular smooth muscle cells. Atherosclerosis 2001; 156: 289-95.

21 Lee SL, Wang WW, Fanburg BL. Association of Tyr phosphorylation of GTPase-activating protein with mitogenic action of serotonin. Am J Physiol 1997; 272: C223-30.

22 Lee SL, Wang WW, Finlay GA, Fanburg BL. Serotonin stimulates mitogen-activated protein kinase activity through the formation of superoxide anion. Am J Physiol 1999; 277: L282-91.

23 Lee SL, Simon AR, Wang WW, Fanburg BL. $\mathrm{H}_{2} \mathrm{O}_{2}$ signals 5-HTinduced ERK MAP kinase activation and mitogenesis of smooth muscle cells. Am J Physiol 2001; 281: L646-52. 